\title{
Lignin-carbohydrate complexes in forages: structure and consequences in the ruminal degradation of cell-wall carbohydrates
}

\author{
A Cornu, JM Besle, P Mosoni, E Grenet \\ INRA-Theix, Unité Digestion Microbienne, 63122 Saint-Genès-Champanelle, France
}

(Received 9 March 1994; accepted 17 June 1994)

\begin{abstract}
Summary - Lignin-carbohydrate complexes (LCCs) are recognised as key structures in forage degradability. Apart from ester bonds involving phenolic acids, which seem to play a major role in grasses, little is known about the other types of linkages that must exist but have proved difficult to demonstrate. The chemical nature of possible LCC linkages is presented and the various mechanisms through which LCCs in the cell-wall architecture may interfere with carbohydrate utilisation by rumen microorganisms are discussed.
\end{abstract}

lignin-carbohydrate complexes / cell wall / forage / digestibility

Résumé - Les complexes lignines-polyosides des fourrages : structures et conséquences sur la dégradation des parois végétales dans le rumen. Les complexes lignines-polyosides (LCC) sont considérés comme des structures clés pour la dégradabilité des fourrages. En dehors des liaisons ester par l'intermédiaire d'acides phénoliques, qui jouent probablement un rôle majeur chez les graminées, on sait peu de choses sur les autres types de liaisons qui devraient exister mais sont très difficiles à mettre en évidence. Dans ce document, nous décrivons les différentes liaisons chimiques proposées, et discutons les mécanismes par lesquels les LCC peuvent interférer avec l'utilisation des polyosides par les microorganismes du rumen.

complexes lignines-polyosides / parois végétales / fourrages / digestibilité

\section{INTRODUCTION}

It is well known that lignins restrict cell-wall carbohydrate degradation in maturing forages. Several studies have shown a negative correlation between lignin content and cell-wall digestibility (Jarrige, 1980; Minson,
1982). However the mechanisms involved in the disproportionate effect on cell-wall digestibility exerted by relatively small amounts of lignins remain unexplained. The effect of lignins (see review by Besle et al, 1995) depends on plant variety and tissue. This is more marked with primary than with secondary walls (Engels and Schurmans, 
1992). The chemical nature of lignins and how they are linked with the other cell-wall polymers seem as important as the total amount of lignin present. This organisation takes place when lignins become anchored to the primary wall (Yamamoto et al, 1989; Terashima, 1993), develops as lignification proceeds (Jung and Deetz, 1993), and continues during cell-wall ageing. It is hypothesized that the lignin-carbohydrate complexes (LCCs) included in the wall structure are key elements in explaining the impact of lignins on cell-wall degradation. Soluble LCCs with predominant lignin moieties have been isolated from the rumen liquor (Gaillard and Richards, 1975; Lomax et al, 1984). In a mechanistic model, Chesson (1993) explained the release of soluble LCCs as a consequence of the degradation of the surrounding carbohydrates. Cell walls were represented as discrete blocks with different compositions. As suggested by Wallace et al (1991), primary layer LCC structures differed from those of the secondary layer. While other aspects of direct and indirect roles of LCCs in cell-wall degradation have been reviewed by Chesson (1988) and Jung and Ralph (1990), this paper presents the state of knowledge about LCC structures in forages and recent concepts concerning their role in cell-wall degradation.

\section{NATURE OF THE LINKAGES BETWEEN LIGNINS AND CARBOHYDRATES}

There are numerous possibilities for the formation of lignin-carbohydrate linkages in cell walls. Firstly, the polymers themselves (polysaccharide and lignin) contain numerous functional groups: primary and secondary alcohols, carboxyls and carbonyls. In grasses, the phenolic hydroxyls of esterified phenolic acids constitute an additional type of functional group. Secondly, enzymes participating in building the cell-wall architecture, such as glycosyl-transferases and peroxidases, are present in multiple forms. Finally, the free radicals and quinone methides produced at the time of lignin polymerisation are very reactive species (see review by Leary, 1980), and have long been suspected of reacting with carbohydrates (Freudenberg and Neish, 1968). In this paper, frequent references will be made to radical and quinone methide reactions. Those reactions have been summarised in figure 1 to illustrate the mechanisms described in the text. Additional information can be found in the review by Ralph and Helm (1993). Other hypothetical reactions, which could lead to the formation of LCC bonds, and which are unrelated to lignin synthesis or occur in the cytoplasmic compartment, are also described.

\section{Linkages involving phenolic acids}

Phenolic acids are precursors of the phenylpropane units of lignins although free phenolic acids are rarely found in cell walls (Newby et al, 1980). However, such acids esterified to lignins or polysaccharides (compound 2 in fig 1) are relatively abundant in grasses and are often referred to as 'noncore lignins' (an inappropriate terminology as discussed by Ralph and Helm, 1993).

It is now well known that grass arabinoxylans are esterified with ferulic acid. Smith and Hartley (1983) purified the first ' $F A X$ ' fragment (O-[5-O-(trans-feruloyl)- $\beta$-L-arabinofuranosyl]-(1->2)-D-xylopyranose) from wheat bran enzyme hydrolysate. Similar structures, but with $\alpha-(1 \longrightarrow 3)$-linked arabinose have since been isolated (table I). A feruloylated xyloglucan fragment ' $F X G$ ' (O-[4-O-(trans-feruloyl)- $\alpha$-D-xylopyranosyl]$(1 \longrightarrow 6)$-D-glucopyranose), has also been isolated from bamboo by Ishii et al (1990). In addition to ferulic acid, grass arabinoxylans have been shown to contain $p$-coumaric esters, and corresponding typical fragments (eg, 'PAXX': O-[5-O-(trans-coumaroyl)- $\alpha-L-$ 


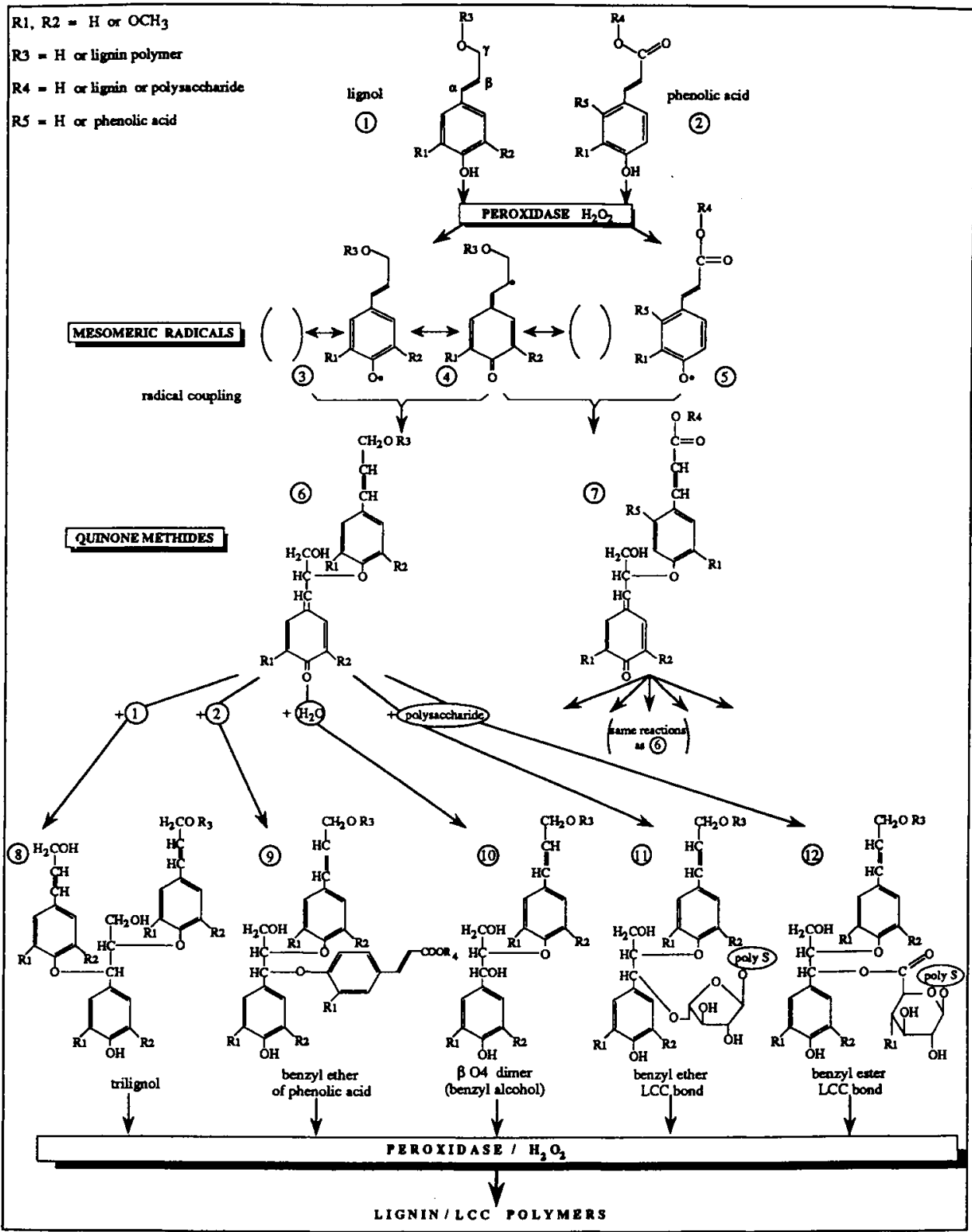

Fig 1. Radical coupling and quinone methide condensation are recognised reactions for binding polysaccharides and phenolic acids to lignins. 

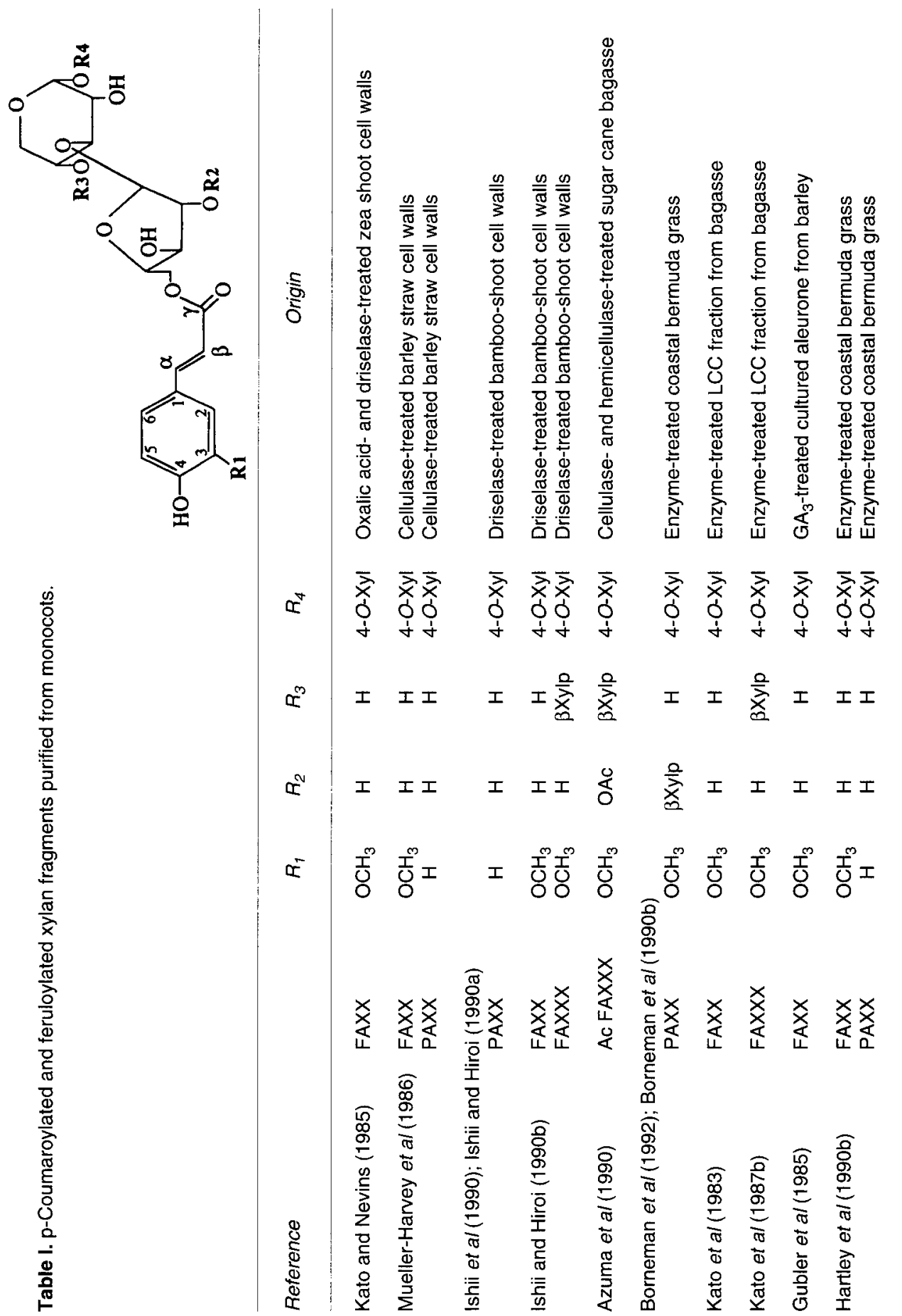
arabinofuranosyl]-(1->3)-O- $\beta$-D-xylopyranosyl- $(1 \longrightarrow 4)$-D-xylopyranose) have been isolated (table I). The frequency of esterification of barley arabinoxylans has been estimated to be about 1 arabinosyl residue every 15 for ferulic acid, and 1 every 31 for $p$-coumaric acid (Mueller-Harvey et al, 1986).

In dicots, ferulic and $p$-coumaric acids are found mainly associated with the pectic fraction and are about 10 times less abundant than in grasses (Jung et al, 1983). Feruloylated pectins have been identified in sugar beet (Rombouts and Thibault, 1986). Fry (1982) isolated 2 types of feruloylated disaccharides: 3-O-(3-O-feruloyl- $\alpha$-L-arabinopyranosyl)-L-arabinose and 4-O-(6-Oferuloyl- $\beta$-D-galactopyranosyl)-D-galactose, which accounted for more than $60 \%$ of the total ferulic acid content of cultured spinach primary cell walls.

Feruloylation invariably occurs at the same position on polysaccharides, which strongly suggests an enzyme-mediated, site-specific phenomenon. Fry (1983) proposed an intracellular esterification at the non-reducing end of newly synthesised spinach pectins. In parsley, in vitro esterification of wall polysaccharides by radiolabelled feruloyl-CoA has been shown to occur in a microsomal subfraction derived from Golgi apparatus (Meyer et al, 1991). However, Yamamoto et al (1989) observed that the kinetics of cell-wall deposition in grasses were different for arabinose and ferulic acid, suggesting an extracytoplasmic esterification. Feruloyl-CoA however, has never been detected in vivo in the cell wall. Although further investigations are needed in order to check if transesterification can occur in the cell wall, different mechanisms could be involved for individual classes of polysaccharides; pectins, which are abundant in primary walls of dicot-cultured cells, may be feruloylated intracellularly, whereas arabinoxylans and xyloglu- cans, predominating in the grass samples studied, could be esterified in the cell wall.

Phenolic esters on cell-wall polysaccharides may undergo 2 distinct types of dimerisation. 5,5'-dehydrodiferulic acid was obtained in vitro from an artificially esterified polysaccharide in the presence of peroxidase and $\mathrm{H}_{2} \mathrm{O}_{2}$ (Geissman and Neukom, 1971). Such biphenyl structures have been observed bridging polysaccharides in spinach (Fry, 1986), wheat flour (Markwalder and Neukom, 1976) and bamboo (Ishii and Hiroi, 1990a), and a diferuloyl hexasaccharide $[X X A F-F A X X]$ has been isolated from bamboo by Ishii (1991). In the cell wall, diferulic bridges probably participate in controlling cell-wall elongation (Fry and Miller, 1989). Diphenyl structures have not been described for $p$-coumaric acid, whereas both ferulic and $p$-coumaric acids have been found in the cyclobutane dimers truxinic and truxillic acid. These dimers are the result of the photochemical coupling of esterified hydroxycinnamic acids (Hartley and Ford, 1989; Hanley et al, 1993; Turner et al, 1993). They have mainly been observed in grasses (Hartley et al, 1990a, b), but are also present in minute amounts in lucerne and red clover stems (Eraso and Hartley, 1990).

$p$-Coumaric acid may also be esterified to lignins in wheat (Smith, 1955) and bamboo (Shimada et al, 1971; Nakamura and Higuchi, 1978). In these and in maize lignins, evidence for ether-linked $p$-coumaric acid has also been obtained ( Nimz et al, 1981). Ferulic acid has also been shown to be etherified to lignins in an LCC fraction from bagasse (Kato et al, 1987a). Scalbert et al (1985) observed in wheat straw that more ferulic acid (25-65\%) than p-coumaric acid $(5 \%)$ was etherified to lignin.

Most of the ferulic acid linkages with lignins are of the ether type while this acid is abundantly esterified to polysaccharides. In contrast, $p$-coumaric acid, mostly esterified to lignins, does not seem to be etherified to polysaccharides. 
The location on lignin units of ester-linked p-coumaric acids has been studied in bamboo and grass by Shimada et al (1971) and Nakamura and Higuchi (1978). The resistance to methanolysis of $p$-coumaric acid esters in lignin fractions compared with that of model compounds indicates that bondings through the $\gamma$-position of the phenylpropane unit predominate over bondings through the $\alpha$-position.

Yamamoto et al (1989) proposed 2 mechanisms for ether bond formation, involving the phenolic group of ferulic acid, which is already esterified on polysaccharide chains. The first was a radical coupling that produces an ether linkage between the phenolic group of the acid and the $\beta$-carbon of the lignin unit (compound 7 in fig 1). The second was described by Scalbert et al (1986), and consists of a nucleophilic reaction resulting in an $\alpha$-ether (compound 9 in fig 1). Both reactions result in bridging lignins to polysaccharides. The existence of [polysaccharide-ester-ferulic-ether-lignin] structures now seems to be established for wheat (liyama et al, 1990), ryegrass (Kondo et al, 1990a) and Phalaris (Lam et al, 1992a).

Likewise, dehydrodiferulic bridges between polysaccharides become etherified to cell-wall polymers during maturation (Lam et al, 1992b), a reaction involving the free phenolic hydroxyls of the dimer and quinone methides.

Ether and ester linkages of phenolic acids can be differentiated by sequential treatments with sodium hydroxide (liyama et al, 1990). Ester-only-, ether-only- and esterether-linked phenolic acids can be distinguished using the method of Lam et al (1992a). The authors confirmed with this method that $p$-coumaric acid, unlike ferulic acid, does not form ester-ether bridges. They also measured the content of esterified and total phenolic acids in internode segments of Phalaris varying in maturity. Ferulic acid appeared at a very early stage of cell- wall building and its total amount quickly stabilised. The proportion of etherified ferulic acid increased more gradually. $p$-Coumaric acid remained mainly in the saponifiable form, and its total content increased continuously during cell-wall building (Lam et al, 1992b). Similar observations were made in ryegrass harvested at different stages of maturity (Kondo et al, 1990a), and in growing culms of sugar cane and rice (He and Terashima, 1991). Ferulic acid can therefore be considered as a component of certain wall polysaccharides, acting as a group for anchoring hydrophobic lignins to hydrophilic carbohydrates, whereas $p$ coumaric acid behaves as a fourth lignin unit. The origin and significance of this individual specialisation of phenolic acids is not clear.

In dicots, the rarity of phenolic acids suggests that lignin anchoring proceeds in a different way and other types of linkages predominate. Joseleau and Gancet (1981) observed in aspen wood alkali-stable ligninaraban complexes held together by alkalilabile lignin-glucuronoxylan linkages, indicating the coexistence of esters with ethers or glycosides.

\section{Linkages involving uronic acids}

Glucuronic acid and its 4-O-methyl derivative occur as side groups in most xylans. In jute fibre (Das et al, 1984a) and in other dicots (Das et al, 1984b; Fry, 1986), they have been shown to be largely, if not totally, involved in ester linkages. The partner molecule was presumed to be a lignin, because lignins were solubilised by treatments that cleave ester bonds.

Esterification of uronic acid side chains of xylans may occur in the cell wall at the time of lignin polymerisation. Tanaka et al (1979) showed in vitro that carboxyl groups (in comparison to secondary and primary alcohols) are the groups most reactive with quinone 
methides leading to the formation of benzylester linkages (compound 12 in fig 1).

Experiments made by Stewart (1973) on eucalyptus wood indicate that uronic acids are also involved in an indirect lignin-xylan bridging: 4-O-methyl-glucoronoxylans bear alkali-labile uronic acid residues (ester-linked to the xylan backbone). Some of these residues were linked to lignins by acid-resistant ether bonds. As many as 7 esterified uronic acids were estimated in each 100 xylose units, 3 of which were etherified to lignins.

Chesson et al (1983) measured the hemicellulosic hydroxyls liberated by an alkaline treatment and estimated that about $30 \%$ of the alkali-labile substituents in grasses as well as in dicots, were not accounted for by acetic and phenolic acids recovered in the extracts. These alkali-labile substituents could have been linked to lignins by alkaliresistant bonds.

Thus, ester linkages seem to play an important part in LCCs. Esters are relatively easy to detect, due to their characteristic infrared absorption at $1730 \mathrm{~cm}^{-1}$, and their sensitivity to mild alkali treatments. It is more difficult to distinguish uronic acid from phenolic acid esters. Borohydride is known to reduce hemicellulosic uronic acid esters to give the corresponding neutral sugar residue. When applied to fibrous material, however, the low yield obtained (Das et al, $1984 a, b)$, suggests a poor accessibility to some ester linkages in situ. Takahashi and Koshijima (1988) showed with model compounds that the use of a high $\mathrm{pH}$ buffer greatly enhances the reduction yield. When applied to LCC fractions from grasses, borohydride does not cleave phenolic acid esters (Morrison, 1974; Tanner and Morrison, 1983; Ford, 1989, 1990). This property, confirmed on model compounds submitted to several hydride reducters, is due to the presence of the conjugated double bond (Lam et al, 1992a). Finally the ester's partner molecule and its linkage position on this molecule need to be identified. Methanolysis or mercaptolysis could prove an interesting method, since the liberated hydroxyl is consequently methylated or thioacylated. Moreover, esters on the $\alpha$-position of a lignol are cleaved, whereas in the $\gamma$-position they are resistant (Nakamura and Higuchi, 1978).

\section{Ether and glycosidic linkages}

It is extremely probable that direct ether and glycosidic bonds occur in LCCs, but conclusive evidence is difficult to obtain for 2 major reasons: they are likely to be very infrequent; and their properties do not allow them to be readily distinguished from intrapolymeric linkages.

Hayashi (1961) reported that $\beta$-glucosidases released new reducing ends as well as new phenolic groups in an LCC from wheat, suggesting the occurrence of phenylglycosidic linkages. Enoki et al (1983) showed that a glycosidic linkage at any position of the lignol could indeed be cleaved by glycanase treatment. Ford (1990) suggested that arabinoxylans from pangola grass could be glycosidically linked to lignins, since borohydride treatment of an LCC fraction resulted in no detectable alditol. In an LCC from aspen wood, Joseleau and Kesraoui (1986) observed monomeric arabinofuranose glycosidically linked to lignin.

Soluble LCCs have been found in the rumen liquor of steers fed on tropical grass (Gaillard and Richards, 1975; Neilson and Richards, 1982). Structural investigations indicated that in these complexes, glucose, xylose and rhamnose were glycosidically linked to lignins (Lomax et al, 1984). In a study on soluble LCCs from the rumen of sheep fed ryegrass, Conchie et al (1988) found reducing xylose and glucose residues, which were throught to be ether-bound to lignins. These fractions also contained rhamnose and appreciable amounts of nitrogen. 
Nordkvist et al (1989) obtained such soluble complexes after in vitro incubation. These LCCs had very low carbohydrate contents and could thus be enriched in sugars directly linked to lignins. However, it is inadvisable to draw conclusions about plant LCC from rumen-soluble LCC studies, due to the lack of knowledge on the microbial transformations that could take place. For example, in aerobic systems, glycosylations occur concomitantly with lignin degradation (Jeffries, 1990). In the rumen, however, lignins are known to be poorly degraded, and such reactions have not been reported.

Benzylethers have been demonstrated in wood lignin-glucomannan and lignin-arabinoxylan complexes by Watanabe et al (1986). Primary alcohol groups of glucose and mannose, and hydroxyls in positions 2 and 3 of xylose were involved, as shown by methylation. These results were obtained by using a selective degradation method with DDQ (2,3-dichloro-5,6-dicyanobenzoquinone) developed for LCC studies by Koshijima et al (1984). DDQ oxidatively cleaves benzylic bonds in the para-position with an electron-donating group. Benzylesters (Watanabe and Koshijima, 1988) and benzylglycosides (Cornu, 1989) are also cleaved by DDQ oxidation.

Model compound experiments by Enoki et al (1983) showed that glycosidic linkages in $\gamma$-, benzylic or phenolic positions are resistant to mild alkali except in the case of syringyl units where they are partially cleaved. Ether bonds in the $\gamma$-position are stable, while benzylethers are more labile (varying with the molecular environment); the presence of a methyl substituent on the phenolic hydroxyl considerably enhances the resistance of benzylether linkages (Enoki et al, 1983; Taneda et al, 1987). Takahashi and Koshijima (1988) observed that sodium hydroxide released significant amounts of xylose from a beechwood LCC, but only traces after methylation of the LCC. DDQ treatment released sugars in proportions similar to those released by alkali, xylose being linked to lignins at $0-3$ or $0-2$. Thus the term 'alkali-labile linkages' includes not only esters, but also some phenolic benzylethers and glycosides involving syringyl units. Morrison (1973) found arabinoxylanlignin complexes in ryegrass alkali-extracts, whereas Al Katrib et al (1988) extracted LCC from $\mathrm{NaOH}$-treated straw, showing the occurrence in these plants of alkali-resistant bonds. From the model experiments of Enoki et al (1983), $\gamma$-ethers would be the most easily distinguishable linkages, since they resist most of the cleavage conditions tested, including strong mineral acid hydrolysis $\left(\mathrm{H}_{2} \mathrm{SO}_{4} 1 \mathrm{~N}, 100^{\circ} \mathrm{C}, 6 \mathrm{H}\right)$.

Benzylethers, like benzylesters, can arise from a reaction between polysaccharide hydroxyl or carboxyl groups and quinone methides (compound 11 in fig 1). Benzylethers also arise spontaneously when phenolic compounds are mixed with sugars (Hemmingson, 1979; Leary et al, 1983). The reactivity of the sugar functional groups decreases from carboxyls to secondary alcohols to primary alcohols, and benzylglycosidic linkages are not favoured (Tanaka et al, 1979). Glycosidic linkages, however, have been obtained in vitro during dehydropolymerisation of coniferyl alcohol by a crude enzyme extract from aspen in the presence of free sugars (Joseleau and Kesraoui, 1986). These authors observed a greater reactivity of arabinofuranose compared to glucopyranose.

A possible mechanism for the formation of glycosidic linkages has recently been described by Kondo et al (1990b), who showed in vitro that $\beta$-glucosidases, which occur in cell walls, catalyse the transfer of a glycosyl residue on acceptor lignols. This reaction is much more efficient if the donor molecule already contains a glycosidic linkage, but has also been observed with free glucose. Primary alcohols $(\gamma)$ are more reactive acceptors than secondary ones $(\alpha)$, and 
the presence of a phenolic hydroxyl results in greater efficiency.

\section{ROLE OF LCC IN RUMEN DEGRADATION OF CELL WALLS}

\section{Mechanistic model of cell-wall degradation}

Chesson (1993) has proposed a precise model for the degradation of lignified cell walls. Cell walls are schematised as being built of bricks representing potentially degradable polysaccharides, with other scattered bricks representing LCCs in the secondary and primary layers. Since cell-wall degradation is considered as a superficial process, the external blocks are removed first by microbial action. Some bricks representing $L C C s$ are released in the rumen medium when the surrounding degradable carbohydrate has been removed, while others remain bound to the cell wall. As degradation proceeds, LCC bricks accumulate at the surface of plant particles, preventing further degradation. The primary wall remains almost intact, either due it being shielded by the external layer, or because the LCC present have a different structure from those in the secondary wall and offer greater resistance (Wallace, 1989). Differences in the rate of formation of the inert layer explains differences in digestibility observed between cell walls. This model also suggests that LCCs may have both negative and positive effects on degradation.

\section{Negative effects of LCCs}

Since lignin preparations added to an in vitro fermentation system do not impede cell-wall degradation (Han et al, 1975; Op den Camp, 1988), the inhibition caused by phenolics is evidently due, directly or indirectly, to link- ages between phenolics and carbohydrates. Hypotheses concerning the role of the diverse structural features of cell walls in preventing polysaccharide degradation have been reviewed by Besle et al (1995). In addition to the physical barrier effect of lignins, lignin-carbohydrate linkages constitute a biochemical barrier sterically hindering glycanases (Jung and Deetz, 1993). In vitro experiments by Gressel et al (1983) have shown that polyeugenol, a lignin model polymer, inhibits cellulolysis only if it is linked to cellulose. Esterification of cinnamic acids to either isolated hemicelluloses (Jung, 1988a) or cellulose (Jung and Sahlu, 1986) will also inhibit glycanolysis. Phenylesterases are produced by rumen fungi (Borneman et al, 1990a) and bacteria (Akin et al, 1993; McDermid et al, 1990). Feruloy esterases liberate ferulic acid from xylan oligomers, synergistically with xylanases, which must first liberate oligomers in the medium (Faulds and Williamson, 1991).

Phenolic acids released in the rumen medium may have a limited antimicrobial effect, which has been shown in vitro (Chesson et al, 1982; Jung and Fahey, 1983; review of Martin, 1990). Likewise, isolated LCCs decrease microbial activity (Cherney et al, 1992). However, except in microenvironments, phenolic acids are produced in subtoxic amounts (Jung and Ralph, 1990) and transformed to phenylpropanoic acid which is considered as a growth factor (Hungate and Stack, 1982). As shown by Besle et al (1988) in a semi-continuous fermentor, it is doubtful that any consequent inhibitory effect appears in vivo. A reduction in microbial adhesion is also possible (Varel and Jung, 1986), but this effect is not significant (Roger and Fonty, personal communication).

\section{Positive effects of LCCs}

Release of soluble LCCs could have positive effects, limiting the shielding of structural 
polysaccharides by lignins. Soluble LCCs accounting for $43 \%$ of the total lignin intake have been found in the rumen liquor of steers fed tropical grass (Gaillard and Richards, 1975). LCCs were also found in the rumen of sheep fed ryegrass (Conchie et al, 1988) and after in vitro incubation of wheat straw (Nordkvist et al, 1989). It is not known if the carbohydrate moiety is further degraded in the rumen, but these compounds probably precipitate in the acidic conditions found in the abomasum (Neilson and Richards, 1978) and the lignin portion is indistinguishable from other lignins in the faeces. Chesson (1981) has shown that an alkali treatment releasing $40 \%$ of barley straw lignin in association with carbohydrates, was sufficient to result in nearly complete in situ degradation of the remaining carbohydrates. Mosoni et al (1993) observed a similar degradation of wheat straw apical internode after a sodium hydroxide extraction that gave $76 \%$ delignification. The positive effect of LCC release in the rumen on carbohydrate hydrolysis may therefore be high. This effect could, however, be partly counterbalanced by some inhibitory effect of soluble LCCs on rumen enzyme activities (Jung, 1988b). An analytical study of the net effect of transformations undergone by LCCs in the digestive tract should be of relevance.

\section{Heterogeneity of the effects of LCCs}

Chesson's model (Chesson, 1993) shows a possible variation of the nature and effects of LCCs within the different layers of the cell wall. Likewise, structural heterogeneity corresponding to diverse cell-wall architecture may also produce different effects on degradation between plant species. This is the case, for example, for differences in cellwall degradation kinetics observed between grasses and legumes. After glycanolysis of Björkman LCCs, the insoluble residue from ryegrass was enriched in phenolic acids and contained more carbohydrates (arabinose and xylose) than that from alfalfa (Kondo et al, 1990c). The authors suggested that ferulic acid could be responsible for the enzyme-resistant bonds in ryegrass LCC. The low phenolic acid content observed in legumes means that direct linkages between lignins and polysaccharides are enhanced. Titgemeyer et al (1992) identified glucuronoxylan fractions from alfalfa stems with a high resistance to degradation, probably due to ester linkages of the uronic side chains with lignins.

No soluble LCCs were found in the rumen of steers eating high quality alfalfa and coastal bermudagrass hay (Windham et al, 1989). Thus, the undigestible residue of these highly digestible forages may contain all the original lignin (8.7 and $3.7 \%$ respectively). This lignin could be of a different type from that found in soluble LCCs of less digestible forages. It could be localised in walls that lignify first, less in weight but more inhibitory.

It should be emphasized that the effects of LCCs on cell-wall degradation, for specific conditions of microbial attack, reflect not only the frequency of recalcitrant linkages, but also result (if a holistic approach is taken) from the combined effects of the various factors determining the cell-wall environment, namely architecture, tissue arrangement, and presence of minerals (silica).

\section{CONCLUSION}

Lignins and hemicelluloses are linked through several types of covalent bonds. Heterogeneity of linkages is observed across plant families and species and within tissues and cell walls. The types of LCCs in the wall are determined by the monomers present and by the process of lignification. Several structures have been suggested or indirectly proposed. Some of these structures are cleaved by the enzymic activities 
present in the rumen and it is not known if totally resistant LCC bonds occur.

Mechanisms explaining the role of LCCs have been suggested. The superficial release of LCCs would have several consequences on cell-wall degradation. The frequency of linkages probably explains a part of the wall resistance but the importance of this resistance is related to all the factors of the cell-wall environment.

Further work is needed to define the structures and to elucidate cell-wall resistance mechanisms. Moreover, it should be worthwile enhancing the positive effect of LCC release and studying the fate of LCCs in the digestive tract in relation to carbohydrate digestion. A more complete understanding of the nature and effects of LCCs may have diverse agronomic consequences: in plant breeding, prediction of nutritional value, and utilisation of low quality forage. It must be noted, however, that the resistance of cell walls to microbial degradation, a drawback in ruminant nutrition, may be an advantage for the plant.

\section{REFERENCES}

Akin DE, Borneman WS, Rigsby LL, Martin SA (1993) pCoumaroyl and feruloyl arabinoxylans from plant cell walls as substrates for ruminal bacteria. Appl Environ Microbiol 59, 644-647

Al Katrib F, Chambat G, Joseleau JP (1988) Isolation of lignin-carbohydrate complexes by use of an organic solvent of cellulose. Cellulose Chem Technol 22, 155-161

Azuma JI, Kato A, Koshijima T, Okamura K (1990) Arabinosylxylotriose mixedly esterified with acetic and ferulic acids from sugar cane bagasse. Agric Biol Chem 54, 2181-2182

Besle JM, Ramihone B, Gochard O, Jouany JP, Tollier MT, Chenost M (1988) Disparition des acides phénoliques de la paille de blé en fermenteur semi-continu : influence de l'acide $p$-coumarique sur la dégradation des glucides pariétaux. Reprod Nutr Develop 28, 155-156

Besle JM, Cornu A, Jouany JP (1995) Transformations of structural phenylpropanoids in cell-wall digestion. FEMS Microbiol Rev (in press)
Borneman WS, Hartley RD, Morrison WH, Akin DE, Ljungdahl LG (1990a) Feruloyl and $p$-coumaroyl esterase from anaerobic fungi in relation to plant cell-wall degradation. App/Microbiol Biotechnol 33, 345-351

Borneman WS, Hartley RD, Himmeisbach DS, LjungdahI LG (1990b) Assay for trans-p-coumaroyl esterase using a specific substrate from plant cell walls. Anal Biochem 190, 129-133

Borneman WS, Ljungdahl LG, Hartley RD, Akin DE (1992) Purification and partial characterization of two feruloyl esterases from the anaerobic fungus Neocallimastix strain MC-2. Appl Environ Microbiol 58, 3762-3766

Cherney DJR, Chemey JH, Patterson JA, Axtell JD (1992) In vitro ruminal fiber digestion as influenced by phenolic-carbohydrate complexes released from sorghum cell walls. Anim Feed Sci Technol 39, 79-93

Chesson A (1981) Effects of sodium hydroxide on cereal straws, in relation to the enhanced degradation of structural polysaccharides by rumen microorganisms. J Sci Food Agric 32, 745-758

Chesson A (1988) Lignin-polysaccharide complexes of plant cell wall and their effect on microbial degradation in the rumen. Anim Feed Sci Technol 21, 219-228

Chesson A (1993) Mechanistic models of forage cellwall degradation. In: Forage Cell-Wall Structure and Digestibility (HG Jung et al, eds), Madison, WI, USA, 347-376

Chesson A, Stewart CS, Wallace RJ (1982) Influence of plant phenolic acids on growth and cellulolytic activity of rumen bacteria. Appl Environ Microbiol 44, 597-603

Chesson A, Gordon AH, Lomax JA (1983) Substituents groups linked by alkali-labile bonds to arabinose and xylose residues of legume, grass and cereal straw cell walls and their fate during digestion by rumen microorganisms. J Sci Food Agric 34, 1330-1340

Conchie J, Hay AJ, Lomax JA (1988) Soluble lignin-carbohydrate complexes from sheep rumen fluid: their composition and structural features. Carbohyd Res $177,127-151$

Cornu A (1989) Synthèse et biosynthèse de composés modèles de complexes lignine-polysaccharides. Thèse de doctorat, Université Joseph Fourier, Grenoble, France

Das NN, Das SC, Mukherjee AK (1984a) On the ester linkage between lignin and 4-O-methyl-D-glucuronoxylan in jute fiber (Corchorus capsularis). Carbohyd Res 127, 345-348

Das NN, Das SC, Sarkar AK, Mukherjee AK (1984b) Lignin-xylan ester linkages in mesta fiber (Hibiscus cannabinus). Carbohyd Res 129, 197-207

Engels FM, Schurmans JLL (1992) Relationship between structural development of cell walls and degradation of tissues in maize stems. J Sci Food Agric 59, 45-51 
Enoki A, Yaku F, Koshijima T (1983) Synthesis of LCC model compounds and their chemical and enzymatic stabilities. Holzforschung 37, 135-141

Eraso F, Hartley RD (1990) Monomeric and dimeric constituents of plant cell walls: possible factors influencing wall biodegradability. J Sci Food Agric 51, 163-170

Faulds CB, Williamson G (1991) The purification and characterization of 4-hydroxy-3-methoxycinnamic (ferulic) acid esterase from Streptomyces olivochromogenes. J Gen Microbiol 137, 2339-2345

Ford CW (1989) A feruloylated arabinoxylan liberated from cell walls of Digitaria decumbens (pangola grass) by treatment with borohydride. Carbohyd Res 190, 137-144

Ford CW (1990) Borohydride-soluble lignin-carbohydrate complex esters of p-coumaric acid from the cell walls of a tropical grass. Carbohyd Res 201, 299-309

Freudenberg K, Neish AC (1968) Constitution and Biosynthesis of Lignin. Springer, Berlin

Fry SC (1982) Phenolic components of the primary cellwall: feruloylated disaccharides of D-galactose and $\mathrm{L}$-arabinose from spinach polysaccharide. Biochem J 203, 493-504

Fry SC (1983) Feruloylated pectins from the primary cell wall: their structure and possible functions. Planta $157,111-123$

Fry SC (1986) Cross-linking of matrix polymers in the growing cell walls of angiosperms. Ann Rev Plant Physiol 37, 165-186

Fry SC, Miller JG (1989) Toward a working model of the growing plant cell wall: phenolic cross-linking reactions in the primary cell walls of dicotyledons. In: Plant Cell Wall Polymers: Biogenesis and Biodegradation (GN Lewis, MG Paice, eds) ACS Symposium Series, 676 p, American Chemical Society, Washington, DC, USA 399, 33-46

Gaillard BDE, Richards GN (1975) Presence of soluble lignin-carbohydrate complexes in the bovine rumen. Carbohyd Res 42, 135-145

Geissman T, Neukom H (1971) Vernetzung von Phenolcarbonsaureestern von Polysacchariden durch oxydative phenolische Kupplung. Helv Chim Acta $54,112-113$

Gressel J, Vered Y, Bar-Lev S, Milstein O, Flowers HM (1983) Partial suppression of cellulase action by artificial lignification of cellulose. Plant Sci Lett 32, 349353

Gubler F, Ashford AE, Bacic A, Blakeney AB, Stone BA (1985) Release of ferulic acid esters from barley aleurone. II. Characterization of the feruloyl compounds released in response to GA3. Aust J Plant Physiol 12, 307-317

Han YW, Lee JS, Anderson AW (1975) Chemical composition and digestibility of ryegrass straw. J Agric Food Chem 23, 928-931
Hanley AB, Russell WR, Chesson A (1993) Formation of substituted truxillic and truxinic acids in plant cell walls - a rationale. Phytochemistry 33(5), 957-960

Hartley RD, Ford CW (1989) Phenolic constituents of plant cell walls and wall biodegradability. In: Plant Cell Wall Polymers: Biogenesis and Biodegradation (GN Lewis, MG Paice, eds) ACS Symposium Series, $676 \mathrm{p}$, American Chemical Society, Washington DC, USA, 399, 137-145

Hartley RD, Morrison III WH, Balza F, Neil Towers GH (1990a) Substituted truxillic and truxinic acids in cell walls of Cynodon dactylon. Phytochemistry 29, 36993703

Hartley RD, Morrison III WH, Himmelsbach DS, Borneman WS (1990b) Cross-linking of cell-wall phenolic arabinoxylans in graminaceous plants. Phytochemistry 29, 3705-3709

Hayashi A (1961) Studies on the chemical combination between lignin and carbohydrate. Part $X$. The existence of phenol- $\beta$-glycosidic bond. $J$ Agric Chem Soc Japan 35, 83-86

He L, Terashima N (1991) Formation and structure of lignin in monocotyledons. IV. Deposition process and structural diversity of the lignin in the cell wall of sugar cane and rice plant studied by ultraviolet microscopic spectroscopy. Holzforschung 45, 191 198

Hemmingson JA (1979) A new way of forming lignin-carbohydrate bonds. Etherification of model benzyl alcohols in alcohol/water mixtures. Aust $J$ Chem 32, 225 229

Hungate RE, Stack RJ (1982) Phenylpropanoic acid: growth factor for Ruminococcus albus. Appl Environ Microbiol 44, 79-83

liyama K, Lam TBT, Stone BA (1990) Phenolic acid bridges between polysaccharides and lignin in wheat internodes. Phytochemistry 29, 733-737

Ishii T (1991) Isolation and characterization of a diferuloyl arabinoxylan hexasaccharide from bamboo shoot cell-walls. Carbohyd Res 219, 15-22

Ishii T, Hiroi T (1990a) Linkage of phenolic acids to cellwall polysaccharides of bamboo shoot. Carbohyd Res 206, 297-310

Ishii T, Hiroi T (1990b) Isolation and characterization of feruloylated arabinoxylan oligosaccharides from bamboo shoot cell-walls. Carbohyd Res 196, 175-183

Ishii T, Hiroi T, Thomas JR (1990) Feruloylated xyloglucan and $p$-coumaroyl arabinoxylan oligosaccharides from bamboo shoot cell walls. Phytochemistry 29 , 1999-2003

Jarrige R (1980) Chemical methods for predicting the energy and protein value of forages. Ann Zootech 29HS, 299-323

Jeffries TW (1990) Biodegradation of lignin-carbohydrate complexes. Biodegradation 1, 163-176 
Joseleau JP, Gancet C (1981) Selective degradations of the lignin-carbohydrate complex from aspen wood. Svensk Papperstidn 84, R123-127

Joseleau JP, Kesraoui R (1986) Glycosidic bonds between lignin and carbohydrates. Holzforschung 40, 163-168

Jung HG (1988a) Inhibition of hemicellulose fermentation by esterified cinnamic acids. J Dairy Sci 71 (suppl 1), 182

Jung HG (1988b) Inhibitory potential of phenolic-carbohydrate complexes released during fermentation. $J$ Agric Food Chem 36, 782-788

Jung HG, Fahey GC (1983) Interactions among phenolic monomers and in vitro fermentation. J Dairy $\mathrm{Sci}$ $66,1255-1263$

Jung HG, Sahlu T (1986) Depression of cellulose digestion by esterified cinnamic acids. J Sci Food Agric 37, 659-665

Jung HG, Ralph J (1990) Phenolic-carbohydrate complexes in plant cell walls and their effect on lignoceliulose utilization. In: Microbial and Plant Opportunities to improve Lignocellulose Utilization by Ruminants (DE Akin et al, eds) Elsevier, 173-182

Jung HG, Deetz DA (1993) Cell-wall lignification and degradability. In: Forage cell-wall structure and digestibility ( $\mathrm{HJ}$ Jung et al, eds) Am Soc Agron, Madjson, WI, USA, 315-346

Jung HG, Fahey GC, Garst JR, Garst JE (1983) Simple phenolic monomers of forages and effects of in vitro fermentation on cell-wall phenolics. J Anim Sci 57 (5), 1294-1305

Kato $Y$, Nevins DJ (1985) Isolation and identification of $O-(5-O$-feruloyl- $\alpha$-L-arabinofurasosyl)-(1->3)O- $\beta$ D-xylopyranosyl-(1->4)-D-xylopyranose as a component of zea shoot cell-walls. Carbohyd Res 137, 139-150

Kato A, Azuma J, Koshijima T (1983) A new feruloytated trisaccharide from bagasse. Chem Lett 137-140

Kato A, Azuma J, Koshijima T (1987a) Björkman LCC from sugar-cane bagasse. Mokuzai Gakkaishi 33, 487-494

Kato A, Azuma J, Koshijima T (1987b) Isolation and identification of a new feruloylated tetrasaccharide from bagasse lignin-carbohydrate complex containing phenolic acid. Agric Biol Chem 51, 16911693

Kondo T, Mizuno K, Kato T (1990a) Cell-wall bound $p$ coumaric and ferulic acids in Italian ryegrass. Can $J$ Plant Sci 71, 495-499

Kondo R, Sako T, limori T, Imamura H (1990b) Formation of glycosidic lignin-carbohydrate complex in the enzyme dehydrogenative polymerisation of coniferyl alcohol. Mokuzai Gakkaishi 36, 332-338

Kondo T, Hiroi T, Mizuno K, Kato T (1990c) Characterization of lignin-carbohydrate complexes of Italian ryegrass and alfalfa. Can J Plant Sci 70, 193-201
Koshijima T, Watanabe T, Azuma J (1984) Existence of benzylated carbohydrate moiety in lignin-carbohydrate complex from pine wood. Chem Lett 1737 1740

Lam TBT, liyama K, Stone BA (1992a) Cinnamic acid bridges between cell-wall polymers in wheat and phalaris internodes. Phytochemistry 31, 1179-1183

Lam TBT, liyama K, Stone BA (1992b) Changes in phenolic acids from internode walls of wheat and phalaris during maturation. Phytochemistry 31, 2655-2658

Leary GJ (1980) Quinone methides and the structure of lignin. Wood Sci Technol 14, 21-34

Leary GJ, Sawtell DA, Wong H (1983) The formation of model lignin-carbohydrate compounds in aqueous solution. Holzforschung 37, 11-16

Lomax JA, Conchie J, Hay AJ (1984) Methylation analysis of soluble lignin-carbohydrate complexes from the sheep rumen. In: Int Works Plant Polysaccharides, Structure and Function (C Mercier, M Rinaudo) Nantes, Nov 1948, INRA, CNRS, p 55

Martin SA (1990) Effect of phenolic compounds on fiberdegrading enzymes from rumen bacteria. In: Microbial and plant opportunities to improve lignocellulose utilization by ruminants (DE Akin et al, eds) Elsevier NY, USA, 289-300

Markwalder HU, Neukom H (1976) Diferulic acid as a possible crosslink in hemicelluloses from wheat germ. Phytochemistry 15, 836-837

McDermid KP, MacKenzie R, Forsberg CW (1990) Esterase activities of Fibrobacter succinogenes subsp succinogenes S85. Appl Environ Microbiol $56,127-132$

Minson DJ (1982) Effect of chemical composition on feed digestibility and metabolisable energy. Nutr Abst Rev 52, 591-615

Meyer K, Kohler A, Kauss H (1991) Biosynthesis of ferulic acid esters of plant cell-wall polysaccharides in endomembranes from parsley cells. FEBS Lett 290 , 209-212

Morrison IM (1973) Isolation and analysis of lignin-carbohydrate complexes from Lolium multiflorum. Phytochemistry 12, 2979-2984

Morrison IM (1974) Structural investigation on the lignincarbohydrate complexes of Lolium perenne. Biochem $J 139,197-204$

Mosoni P, Besle JM, Cornu A, Duran H, Jouany JP (1993) Wheat lignin labelling using [U-14C] phenylalanine or $\left[\mathrm{O}^{14} \mathrm{CH}_{3}\right]$ sinapic acid to study the fate of lignin in the rumen. $J$ Agric Food Chem 41, 1349 . 1354

Mueller-Harvey I, Hartley RD, Harris PJ, Curzon EH (1986) Linkage of $p$-coumaroyl and feruloyl groups to cell-wall polysaccharides of barley straw. Carbohyd Res 148, 71-85

Nakamura Y, Higuchi T (1978) Ester linkage of $p$ coumaric acid in bamboo lignin. Il. Synthesis of 
coniferyl $p$-hydroxybenzoate and coniferyl $p$ coumarate as possible precursors of aromatic acid esters in lignin. Cellulose Chem Technol 12, 199208

Neilson MJ, Richards GN (1978) The fate of soluble lignin-carbohydrate complex produced in the bovine rumen. J Sci Food Agric 29, 513-519

Neilson MJ, Richards GN (1982) Chemical structures in a lignin-carbohydrate complex isolated from the bovine rumen. Carbohyd Res 104, 121-138

Newby VK, Sablon RM, Synge RLM, Casteele KV, Van Sumere CF (1980) Free and bound phenolic acids of lucerne (Medicago sativa cv Europe). Phytochemistry $19,651-657$

Nimz HH, Robert D, Faix O, Nemr M (1981) Carbon-13 NMR spectra of lignins. 8. Structural differences between lignins of hardwoods, softwoods, grasses and compression wood. Holzforschung 35, 16-26

Nordkvist E, Graham H, Aman P (1989) Soluble lignin complexes isolated from wheat straw (Triticum arvense) and red clover (Trifolium pratense) stems by an in vitro method. $J$ Sci Food Agric 48, 311-321

Op den Camp HJM, Verhagen FJM, Kivaisi AK et al (1988) Effects of lignin on the anaerobic degradation of (ligno) cellulosic wastes by rumen microorganisms. Appl Microbiol Biotechnol 29, 408-412

Ralph J, Helm RF (1993) Lignin/hydroxycinnamic acid/polysaccharide complexes: synthetic models for regiochemical characterization. In: Forage Cell Wall Structure and Digestibility (HG Jung et al, eds) Am Soc Agronomy, Madison, WI, USA, 794 p, 201246

Rombouts FM, Thibault JF (1986) Feruloylated pectic substances from sugar beet pulp. Carbohyd Res $154,177-187$

Scalbert A, Monties B, Lallemand JY, Guittet E, Rolando $C$ (1985) Ether linkage between phenolic acids and lignin fractions from wheat straw. Phytochemistry $24,1359-1362$

Scalbert A, Monties B, Rolando C, Sierra-Escudero A (1986) Formation of ether linkage between phenolic acids and gramineae lignin: a possible mechanism involving quinone methides. Holzforschung 40, 191 195

Shimada M, Fukuzuka T, Higuchi T (1971) Ester linkages of $p$-coumaric acid in bamboo and grass lignins. TAPPI 54, $72-78$

Smith DCC (1955) Ester groups in lignin. Nature (Lond) $176,267-268$

Smith MM, Hartley RD (1983) Occurrence and nature of ferulic acid substitution of cell-wall polysaccharides in graminaceous plants. Carbohyd Res 118 , 65-80

Stewart CM (1973) Complexes of glucuronoxylan, uronic acid and lignin in eucalypt wood. Cellulose Chem Technol 7, 691-701
Takahashi N, Koshijima T (1988) Molecular properties of lignin-carbohydrate complexes from beech (Fagus crenata) and pine (Pinus densiflora) woods. Wood Sci Technol 22, 177-189

Tanaka K, Nakatsubo F, Higuchi T (1979) Reactions of guaiacyclycerol- $\beta$-guaiacyl ether with several sugars. II. Reactions of quinonemethide with pyranohexoses. Mokuzai Gakkaishi 25, 653-659

Taneda $\mathrm{H}$, Nakano J, Hosoya S, Chang HM (1987) Stability of alpha-ether type model compounds during chemical pulping processes. $J$ Wood Chem Technol 7, 485-498

Tanner GR, Morrison IM (1983) The effect of saponification, reduction and mild acid hydrolysis on the cell walls and cellulase-treated cell walls of Lolium perenne. J Sci Food Agric 34, 137-144

Terashima N (1993) Formation and ultrastructure of lignified plant cell walls. ISWPC 1, 24-33

Titgemeyer EC, Bourquin LD, Fahey GC (1992) Disappearance of cell-wall monomeric components from fractions chemically isolated from alfalfa leaves and stems following in situ ruminal digestion. J Sci Food Agric 58, 451-463

Turner LB, Mueller-Harvey I, MacAllan AB (1993) Lightinduced isomerization and dimerization of cinnamic acid derivatives in cell walls. Phytochemistry 33, 791-796

Varel $\mathrm{VH}$, Jung $\mathrm{HJ}$ (1986) Influence of forage phenolics on ruminal fibrolytic bacteria and in vitro fiber degradation. Appl Environ Microbiol 52, 275-280

Wallace $\mathrm{G}$ (1989) A study of phenolic-carbohydrate linkages in the Gramineae. PhD Thesis, Univ Glasgow, UK

Wallace G, Chesson A, Lomax JA, Jarvis MC (1991) Lignin-carbohydrate complexes in graminaceous cell-walls in relation to digestibility. Anim Feed Sci Technol 32, 193-199

Watanabe T, Koshijima T (1988) Evidence for an ester linkage between lignin and glucuronic acid in lignin carbohydrate complexes by DDQ oxidation. Agric Biol Chem 52, 2953-2955

Watanabe T, Kaizu S, Koshijima T (1986) Binding sites of carbohydrate moieties toward lignin in LCC from Pinus densiflora Wood. Chem Lett 11, 1871-1874

Windham WR, Himmelsbach DS, Amos HE, Evans JJ (1989) Partial characterization of a protein-carbohydrate complex from the rumen of steers fed highquality forages. J Agric Food Chem 912-915

Yamamoto E, Bokelman GH, Lewis NG (1989) Pheny|propanoid metabolism in cell walls: an overview. $\mathrm{ln}$. Plant Cell Wall Polymers: Biogenesis and Biodegradation (GN Lewis, MG Paice, eds) ACS Symposium Series, 676 p, Am Chem Soc, Washington, DC, USA, $399,68-88$ 